\title{
Naked elites: unveiling embodied markers of superiority through co-performance ethnography in gentrified Brooklyn's Park Slope
}

\author{
Lidia Katia Consiglia Manzo \\ Faculty of Sociology, The University of Trento, Trento, Italy
}

\begin{abstract}
In the super-gentrified neighborhood of Brooklyn's Park Slope, elites joined democratic associations, such as karate dojos or food coops, to interact with and become socially accepted by the local community. Co-performance ethnography made it possible to recognize that progressive moral values led instead to exclusive behaviors. Drawing on symbolic interactionism and socio-cultural analysis, this article provides a definition of performance as the paradigm-driven methodological tool to unveil the hidden, micro-strategies of elite reproduction. I analyze how social mixing in gentrified neighborhoods encourages competing identities to reproduce symbolic boundaries, ultimately serving as a basis for socio-spatial inequality and conflict. The production of identities, behavior, and emotions highlights elites performance of a contextualized version of "self" to assert their superior status. It also shows how these relations of domination shape elites' lives. These points call attention to the connections between capital accumulation and the hermeneutical agency of the body.
\end{abstract}

\section{ARTICLE HISTORY}

Received 2 October 2016

Accepted 3 September 2017

\section{KEYWORDS}

Economic elites; gentrification; co-performance ethnography; theory of the self; symbolic boundaries

\section{Introduction}

Key global processes of gentrification (Lees, Shin, \& Lopez-Morales, 2015, 2016) and financialization (Aalbers, 2016; Sassen, 2014) have been a catalyst to urban research in the exclusionary effects of the growing domination of affluent elites in the contemporary city (Bridge, Butler, \& Lees, 2012; Butler \& Lees, 2006; Lees, 2008, 2013; Lees \& Ferreri, 2016; Rose et al., 2013; Slater, 2006; Zukin, Kasinitz, \& Chen, 2015). In the United States, the concentration of income and wealth among elites has increased dramatically since the early 1980s, peaking in the early 2000s (Atkinson \& Piketty, 2010; Keister \& Lee, 2014). Particularly in the last decade, the City of New York has attracted a growing population of wealthy foreigners facilitating the workings of capitalism through global financial investment (Aalbers, 2008; Fields, 2015; Krippner, 2005) that has transformed the City's real estate market (Story \& Saul, 2015), as well as its socio-cultural fabric (Zukin, 1982, 2010). However, the implications of these rapid

CONTACT Lidia Katia Consiglia Manzo@lidia.manzo@gmail.com; Lidia.Manzo@mu.ie $\Theta$ Department of Geography, Maynooth University, Rhetoric House, Maynooth, Co. Kildare, Ireland

Present affiliation for Lidia Katia Consiglia Manzo is Department of Geography, Maynooth University, Maynooth, Co. Kildare, Ireland 
transformations on the lives of ordinary urban dwellers, especially those with limited economic resources, are poorly understood (Slater, 2009).

While there has been a proliferation of publications in recent years with respect to critical and geographical accounts of the economic elite (Bennett et al., 2009; Fernandez, Hofman, \& Aalbers, 2016; Hay, 2013), these studies have not connected those macro political-economic and geographical processes with the "micrological textures of power" (Katz, 1992, p. 264) involved in the social reproduction of class inequality. This is particularly true with regard to social and economic domination of the upper classes at the community and neighborhood levels. There is little analysis or recognition of the ways they think or act in interactions with people of lower classes. Elites engage in everyday practices with these city dwellers. Unlike in other settings, they are not the ruling actors in these particular situations. For the most part, economic elites are seen as those who exude their class privilege and symbols of high social status through their conspicuous consumption preferences (Myers \& Kent, 2004; Veblen, 1899) and distinct, reserved lifestyle. For example, economic elites often isolate themselves in luxurious, gated communities or exclusive, suburban country clubs (Beaverstock, Hubbard, \& Short, 2004; Borsdorf \& Hidalgo, 2008; Cousin \& Chauvin, 2013, 2014; Pow, 2011). On the contrary, Andreotti, Le Galès, and Moreno-Fuentes (2015) found that, despite the rise of high-skilled professional global mobility, upperclass people are profoundly embedded and territorialized in their cities and neighborhoods.

Utilizing a symbolic interactionist ${ }^{1}$ approach and drawing on Lamont's (1992) and Bourdieu's (1984) socio-cultural theories of class and distinction, this article has two goals: 1) to define a heuristic method for the investigation into how cities' elite populations produce class divisions and 2) to examine the performative dimension of elitist behavior by documenting the production of symbolic boundaries in inter-class interactions. This paper addresses the conditions under which symbolic boundaries generate inequality and exclusion, contributing to existing literature on the role of internal, embodied manifestation of superiority in the geography of urban elite.

The article presents evidence from an ethnography conducted in Brooklyn's Park Slope, one of the most desirable neighborhoods of New York City, that, in the last 40 years, has been the "frontier" (Smith, 1996) of intense investment and conspicuous consumption. Today, Park Slope is a super-gentrified urban community (Lees, 2003; Manzo, 2014; Slater, 2003) populated by economic elites that represent a sample of the top one percent earners in the United States: chief executive officers, celebrities, doctors, lawyers, media entrepreneurs, and Wall Street financiers. Two ethnographic case studies were chosen: a popular martial arts studio and a food cooperative market. These two unique places are governed by distinct social codes. For example, in a karate dojo, it does not matter if you are a "White, well-educated financier" or a "West Indian construction worker." The value of your practice, the level of your belt, and an unconditional respect for the Master are the only power forces at play. At the Food Coop, all members are equal because, in order to shop there, one must volunteer 2 hours and 45 minutes every four weeks with a group of the other 16,000 members. The socio-demographic composition of Coop members strikingly resembles that of the entire borough of Brooklyn. The karate dojo and the food coop were both critical cases as they represented the least likely places in which to find practices of elite distinction. 
Ethnography helped understand that elite reproduction still takes place in these settings. When they are "nakedly exposed" in non-elite spaces, elites do not have the ability to control the system of norms and values. Thus, far more subtle micro-strategies are required to distinguish themselves from others. The notion of "off-stage" practices is central to this argument and is the key for the interpretation of signs of superiority within the upper class. These signs are unveiled in interactions where elites must "take off" their social status and, consequently, surrender their power.

To understand performance as the paradigm-driven methodological tool to explore expressive and embodied micro-elements of elite reproduction, I first summarize how this paradigm is applied to the field of urban ethnography in elite research. This summary is followed by an analysis of the conceptual apparatus that informed my field research and provide empirical evidence of how co-performance activities allow the ethnographer the opportunity to study embodied forms of elite distinction more in depth. Lastly, I discuss the complexity and ambiguity of elites' relations of domination. I also highlight how they impose their moral positions on local communities in everyday practices, challenging critical geographers to engage in symbolic interactionism to refine our knowledge of how issues of distinction, segregation, and hegemony work spatially.

\section{The performance paradigm in urban elite ethnographies}

The performative turn in ethnography has progressed beyond the recognition that social life is performative, moving toward an understanding of performance as a paradigm and a tool for conducting research anchored in dialogue, praxis, and the politics of resistance (Conquergood, 1989; Denzin, 2014; Turner \& Bruner, 1986). Linked to the epistemological and political commitment of critical geography, this perspective privileges embodied forms of research centered on the ethnographer's negotiated and delicate face-to-face encounters.

Turner advocates for performance-sensitive research (1986) by pointing out the determinant role of the ethnographer in "coactivity," or as a co-performer able to understand embodied meanings "on their pulses" (1975, p. 29). If performance applies to both the researcher and the researched (Conquergood, 1991, 1992), the engagement in a "shared" fieldwork experience becomes an hermeneutical agency, a more intersubjective sphere that enables the interpretation and transfer of knowledge (M. Jackson, 1989). According to Butler, performance is the perspective from which to delve into the embodied construction of identities "through language, gesture, and all manner of symbolic social sign" (1988, p. 519). Therefore, co-performance activities allow the researcher to gather undetermined aspects of social interaction. The researcher experiences the very same evaluations that emerge out of participating in shared experiences. These experiences can usually only be understood through the examination of how different individuals come to interpret situations distinctly, but performance ethnography allows the researcher to understand these firsthand (Hutter, 2012).

According to Thrift (2008), geographers should focus on non-representational work as a way to understand meaning as not residing in something but as generated through processes. Attention to "multiplying performative methodologies" present new concerns for urban researchers, "which allow their participants equal rights to disclosure, through dialogical actions rather than texts, through relation rather than representation" (Ibid., p. 
148). Within the move to performance in geography (Gregson \& Rose, 2000) and the recent interest shown in the embodied aspects of identity in situated contexts (Clifford, Cope, Gillespie, \& French, 2016), the approach followed in this article can be traced to Goffman's analyses of interaction and the performing self (Goffman, 1956, 1983).

\section{Theoretical perspectives on distinction, symbolic boundaries, and the significance of the information given when the self is "OFF"}

The study of elite distinctiveness is understood in this work as the study of a performance in an evolving process, rather than a constant postulate or premise (J. Clifford, 1988; Conquergood, 1991). The creation and maintenance of distance recalls basic processes in social life that emphasize the boundaries between those included (the pure) and those excluded (the impure) across different groups (Durkheim, 1965; Simmel, 1950). Within this tradition, the tacit "symbolic boundaries," (Lamont \& Fournier, 1992; Lamont \& Molnár, 2002) conceptual distinctions that we make to categorize our experiences, are particularly relevant in this endeavor. Lamont argues that "[b]oundary work is an intrinsic part of the process of constituting the self" (1992, p. 11, italics is mine). Elites use symbolic boundaries in the process of performing their identity and class status, especially in relations with lower classes, to sustain a sense of superiority. Such a performance is used to enforce, maintain, normalize, or rationalize inter-class divides, in sum contributing to class reproduction. However, basic inferences of similarities and differences that define identity often allow an "unintended effect" to transpire.

Actual processes of embodiment of dominant class dispositions, or habitus, are indeed reiterated in practice ${ }^{2}$ and played out accordingly to distinction, as significantly analyzed by Bourdieu (1984). Central to his thesis are the less obvious expressions of material domination - defined in this article as embodied markers of superiority. According to Auslander, social stratification appears clearly in practices embedded in a particular habitus "because class inequalities and the dominance of one class over another occur covertly. Rather than the application of overt force, symbolic power is harnessed to maintain class distinction and the appearance of their naturalness" (2008, p. 69). To account for the embodied forms of elite distinction, researchers have to observe "more subtle, but also more deeply anchored means of demonstrating social worth" (Daloz, 2010, p. 81). However, this may not be an easy feat. Elites' attitudes of superiority are not officially or too openly expressed, and they may be abstruse in interactions with those of other social classes where they may feel obligated to "level the playing field" with regard to external symbols of wealth. In this light, Bourdieu's argument underlines a heuristic method for thinking about the significance of the information given during more hidden practices, those aforementioned "unintended effects", eventually linking his view to that of theatrical production as social practice.

Goffman's dramaturgical model (1956) of the micro order of interaction is of particular interest and can be conceptually employed in the understanding of how elites convey such signs of superiority. By using the "stage" and the "theatre" as key organizing metaphors, Goffman sustains how versions of a "self" are differently played out in more or less public performances accordingly to "front" or "back" spatial regions. Particularly, the term back "refers to the area where the actor(s) are 'offstage' and can relax, let their guard down" 
(Richards, 2001, p. 61). The symbolic interactionist agenda and the importance of role and self-presentation came to dominate social psychological theorizing about the self. Works on social identity theory have contributed enormously to our understanding of intergroup relations and group processes (Abrams, 1996; Abrams \& Hogg, 2001; Hogg, 2001; Stets \& Burke, 2000). This research has encouraged the integration of different levels of conceptualization and explanation of the performance of self. Different components of the self-structure combine to embody differing goals and a "salience hierarchy" (Stets \& Burke, 2000, p. 231) is involved in the enactment of a performance in a particular context when more than one self may be appropriate. Therefore, the definition of context and the conditions that might determine it become of extreme importance when we think about the negotiation of different "self-conceptions" (Abrams, 1996, p. 145) in inter-class symbolic boundaries. This negotiating process forces elites to resolve the "distress" between the enactment of their "private" self with cognitions on one's own attitudes, traits, feelings, "collective" self - with cognitions about group memberships and affiliations of all types, or a combination of the two.

According to Goffman (1951), close observations that consider "the pressures that play upon behavior" (p. 295) in social situations provoke both expressions given ON and expressions given OFF, with the latter being "the more theatrical and contextual kind, the nonverbal, presumably unintentional kind" (Goffman, 1956, p. 16). This raises questions about the social significance of the information given OFF. Information given OFF is significant because it allows inherent signs of class habitus to transpire.

\section{Park slope, the gold coast of victorian brooklynites and super-gentrifiers}

The "corporatization of gentrification" in New York City reflects the city's dramatic post-industrial socio-economic changes (Lees, 2000; Smith \& DeFilippis, 1999). The phenomenon has contributed to the redevelopment and rebirth of formerly industrial areas into chic residential communities, making Park Slope one of the most fashionable neighborhoods of southwestern Brooklyn (see map in Figure 1).

After the Great Depression, the "White flight" of urban dwellers led residents to the suburbs in the mid-1900s. Today, Park Slope is once again becoming a neighborhood for the rich, as it was up until the end of the 19th century, when the lawyer and railroad magnate Edwin Litchfield sold 526-acres of what eventually became Prospect Park, ${ }^{4}$ to New York City. Park Slope was Brooklyn's Gold Coast (K. T. Jackson, 2004), a distinguished place for the extremely wealthy to develop vacant property and live. The grandiose mansions and charming Victorian brownstones built by those early elites proved to be an architectural anchor that attracted the first wave of gentrifiers to Park Slope more than a century later (Osman, 2011).

Park Slope's reputation as a hub for elites is further supported by its well-designed public places and urban landscapes. Other key place-making elements include: two lively commercial corridors (Fifth Avenue and Seventh Avenue); multimodal transit stops; upscale music venues; trendy bars and lounges; a diverse dining scene, which includes minimalist coffee shops; and community initiatives. International college students, young families taking advantage of excellent local public schools, elderly residents born and raised in Park Slope, and wealthy professionals searching for luxurious mansions and progressive attitudes all live alongside one another in Park Slope's brownstones (Manzo, 2012). 


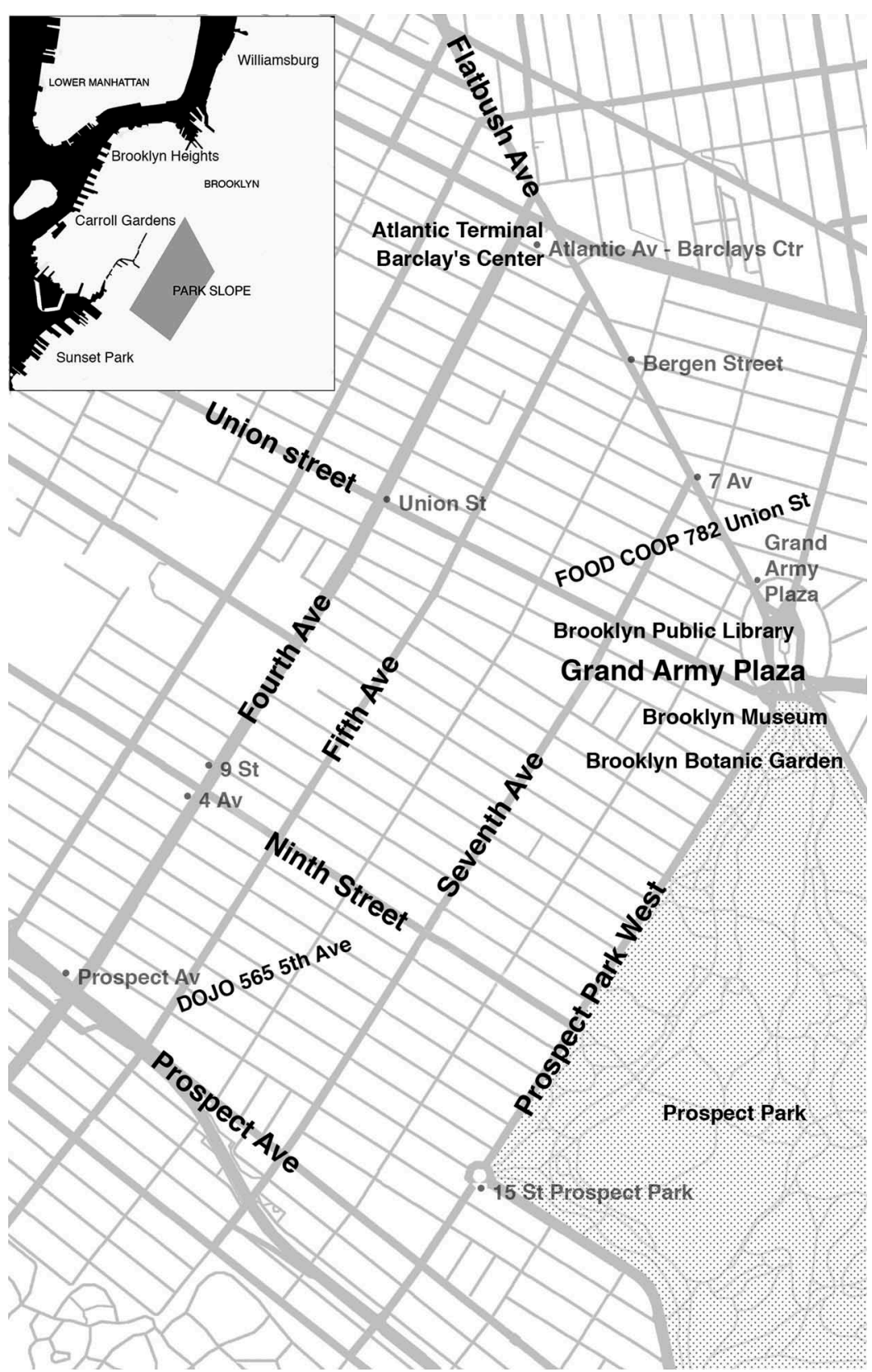

Figure 1. Brooklyn's park slope and its adjoining neighborhoods (Credit: Scott Lizama).

Park Slope has evolved from being predominantly White European (Irish, Polish, and Italian), White Hispanic, and Non-Hispanic Black to a White neighborhood. This transition occurred through an influx of White gentrifiers who do not identify with longstanding ethnic minorities (see Manzo, 2014). However, while the racial make-up of Park Slope has not changed much, neighborhood residents have become increasingly wealthier, better educated, and more heavily involved in professional occupations and 
in the financial services industry. The most dramatic change in Park Slope has been the increase in incomes, with the most rapid increase taking place during the 1980s and after the 1990s. Over the past 40 years, the median household income in Park Slope has increased by $1,162.8$ percent - double the citywide rate. ${ }^{5}$ These changes point to what Lees (2003) calls "super-gentrification."

In the following section, I introduce the two ethnographic settings where the study was conducted. These represent only part of a larger project that addressed the influences of displacement, housing-abandonment, and resettlement in the forty years that Park Slope was undergoing super-gentrification. The research consists of two and half years of ethnographic fieldwork mostly conducted in 2011 and 2012, with shorter follow-up studies in 2013, 2015 and 2017.

\section{Tune your body up: the ethnographer as co-performer}

The aim of the following section is aid the learning process by describing: 1) the choice of the two ethnographic settings; and 2) the strategies employed to gain access to them and the author's position as co-performer. This section concludes with a discussion of ethnographic data that provide evidence of performance as a paradigm-driven methodological tool that facilitates the study of embodied elements of elite reproduction.

\section{Setting the stage: introducing the food co-op and the karate Dojo}

One possibility for mitigating uncertainties of urban ethnography is to use fixed, real places with definitive boundaries; this tactic was used to select the case studies. Two distinct kinds of semi-private places were chosen along the lines of two criteria: both had to attract the economic elites of Park Slope as patrons, but they could not be the ruling actors. In such a way, the elite would have to interact with their lower class counterparts "equally". I found that the martial arts studio Japan Karate Association of Brooklyn and the food cooperative market Park Slope Food Co-op (PSFC) met the aforementioned criteria. Both were founded in the early 1970s and were built upon the values of democracy and member equality. Since then, they have welcomed members of multiplicity of genders, races, social classes, political affiliations, religious beliefs, and sexual orientations. For the purposes of this research, the assumption was made that one could find the entire spectrum of diversity within both spaces. Both had the potential to mirror the socio-demographic changes that occurred in the previous 40 years. As David, one of the elite members of the dojo pointed out,

$[\mathrm{k}]$ arate, having its own set of rules, it is kind of a very neutral space. For instance, I know next to nothing about the lives of people of the dojo outside the dojo, and they're people who I probably wouldn't associate with outside that context. I might, but I don't know that I would. It's kind of cool because you'll have this group of people who are quite dissimilar from each other: very different backgrounds, very different ages, and very different professions. But they are all sort of brought together by this activity that they're doing together (...) you form some degree of a social connection with these people, even though there aren't other circumstances where that would happen. I mean I don't know when I would ever have a chance to interact with that kind of person socially. (" After training conversation ", March.6.2015) 
I also found them appropriate ethnographic settings for three important social reasons. First, the elite use the arts, sports, and "foodie-ism" as symbols of class prestige. Second, it is not particularly difficult for one to join one of these organizations. Membership requires the acceptance of their internal rules and payment of a membership fee (excluding the external issue of gaining access to elites' social network and sphere). Finally, I could enrich my research by joining an organization I had previously been involved with, as well as one that was completely new to me. Karate dojo, was already "familiar territory" (Hoggart, Lees, \& Davies, 2002, p. 267) for me. Having been a karate practitioner for over twenty years and having had the chance to train already in that specific dojo, ${ }^{6}$ I was confident in my ability to develop the network of research contacts through these practitioners and gatekeepers. On the other hand, knowing very little about the food co-op gave me the opportunity to understand the interactions and behavior from another perspective (van Maanen, 1988). The martial arts studio had a thirty adult member capacity, and the oldest American food cooperative had 16,000 members. Thus, I could observe how intimate relationships affect human behavior and interaction differently from vaster membership and diversity.

At the karate dojo, located on the southern end of Park Slope's Fifth Avenue, the master's teachings of Shotokan style are profound and exhaustive, with training that focuses on basics, form, and sparring. Karate practitioners must learn to work together with respect and courtesy, and they must always practice karate safely but effectively. "Throughout their study of karate, students are constantly forced to reflect upon themselves, their attitude and their behavior" (Umezawa, 1998, p. 10). The dojo is composed of a community of practitioners from a variety of class backgrounds and ethnicities. At the dojo, one's financial standing or class/educational background does not matter; one achieves stature by merit. The ritual of the gi, or uniform, is an equalizer. The only difference in uniform is the belt, which distinguishes one's rank. A dojo is not a temple, as karate is not a religion; however, there are some simple rules of respect. One should bow upon entering and exiting the dojo as well as help maintain and clean the space. Every member, including the master, must respect the five precepts of karate, the dojo kun. ${ }^{7}$ These are as follows: 1) strive for perfection of character; 2) be faithful and protect truth; 3) endeavor; 4) respect others and the rules of etiquette; and 5) refrain from violent behavior.

The PSFC is the oldest and largest active American members-only food cooperative. It is located on Union Street. Its mission is, "Good Food, at Low Prices for Working Members, through Cooperation," and Park Slope residents (and local media outlets) describe it as a space "where elite lefties meet to share organic recipes as they gossip about social justice and the best private schools" (Peyser, 2011). Since 1973, it has been providing Brooklyn and beyond with quality food and products, while serving as a community center and meeting place for its member-owners: people who believe in the value, rewards, and responsibility of collective labor, action, and ownership. Similarly to the dojo, the democratically-controlled PSFC is founded upon five values: 1) equity and equality; 2) self-help; 3) self-responsibility; 4) democracy; and 5) solidarity.

Despite gentrification which has altered the landscape of different areas within Park Slope since the late 1970s (Manzo, 2014), both the karate dojo and the PSFC have maintained their lower-class members. Even former residents that were priced out of the neighborhood's rental market did not abandon training with their karate master or 
purchasing affordable, organic food. I observed members of both institutions traveling from all New York City boroughs and even Jersey City. These equality politics catered to lower class members through the provision of affordable or reduced membership fees and extended payment plans.

\section{Gaining access to the field}

The most important step of the research process was gaining access to the two settings in ways that were appropriate, ethical, and effective (Madison, 2005). To be successful there are no particular secrets beyond authentic, profound commitment, open-mindedness, and a reliable, sincere interest, which informants always seem to perceive in the researcher. Indeed, coperformance ethnography requires the researcher to also enter into a specific fieldwork situation with a "tuned-up body," as suggested by Goffman, to have "the right to be close to them" (1989, pp. 125-126) and access embodied knowledge.

At the karate dojo, I performed an adult, third $\mathrm{dan}^{8}$ black belt, beginning in January 2011. As a skilled karate practitioner, the Brooklyn dojo allowed me to outline a preliminary framework of community understanding. However, being a female black belt in a place that is dominated by male practitioners, I had to show them that I was just as "tough." It took me two months of very hard training to earn "a position of respect" within the dojo. My new reputation, which I could have only obtained through my personal karate skills, had an inestimable value during the course of the data collection phase of my research.

I joined the PSFC in May 2011. I worked as a volunteer member in many different positions, including shopping assistant, cashier, co-counter attendant, and maintenance worker. I also sliced, prepared, and packaged cheeses, olives, spices, and dried fruits to be sold in the market.

Something that was unanticipated when I designed my research was the opportunity to be perceived very differently in the two settings. Due to my level of experience with karate I soon became part of the dojo advanced practitioners group, mostly composed of, "longterm working class residents." On the contrary, being a well-educated, White European woman in her late 30s with a different accent, mannerisms, and cultural background from the long-term Brooklynites, people at the coop thought of me as one of the, "upper class volunteer members." Following Katz's solution, I explored myself in the "spaces of betweenness" (1992, p. 506). I found explicit connections between the constant reflexive reposition and political practice of myself and those with whom I co-performed.

All research informants with whom I worked directly were aware of the purpose of my study and consensually shared their feelings, perceptions, and data about their socio-demographic background and lifestyles. The negotiation of trust revolved around the ethic: do not harm research participants and protect their anonymity. Nevertheless, to mitigate intrusiveness, I decided to record my observation in the research diary in privacy (Hoggart et al., 2002).

\section{Co-performing off-stage elite practices}

This section delves into the discussion of elitist signs of superiority, as analyzed in the two ethnographic settings. There is no method to reduce these signs to one single 
rationale because they represent a more complex frame. Nevertheless, a typology has been outlined to guide the reader through the categorization of performances on the path to creating symbolic boundaries (see Figure 2).

In the case of the karate dojo and the food co-op in Park Slope, elites have to "face" two distinct yet class-diverse group settings with similar norms of conduct based on the principles of democracy and equality. A major contradiction is that the aspiration toward such progressive moral values lead instead to hegemonic stylized acts of "exclusive behaviors" (Lamont, 1992, p. 10). As mentioned in the introduction, selfawareness is taken "off" in certain settings, and elites deviate from group norms to boost their self-esteem and reduce uncertainty (Abrams \& Hogg, 2001; Hogg, 2001; Stets \& Burke, 2000). This study showed that structural status-based differentiations were accentuated in places where elites exercise coercive power to remedy a perceived lack of power. Elitist performances resulted in either successful distinction and domination or anti-social practices and excessive frustration. The latter was the case when elites failed to exert power. The creation of symbolic boundaries is related to the definition of context. The elites attempted to define the context more broadly in order to incorporate that social sphere in which they are privileged. Non-elites attempted to define the context more narrowly to eliminate the disadvantages they face outside this social space.

Exertion of distinction and domination is evident in both settings, despite the fact that elites "take off" most of their external signs of wealth by changing into

\section{Symbolic \\ Boundary}

Form

Context

Level of

Self-Attention

Activation

Categorization

Case

Type of

Performance
HEGEMONIC STYLIZED ACTS OF EXCLUSIVE BEHAVIOR

Embodied Markers of Superiority

Inter-class Interactions within Group Dynamics

OFF-stage (unintentional)

Maintenance of High Self-esteem and Reduction of Uncertainty

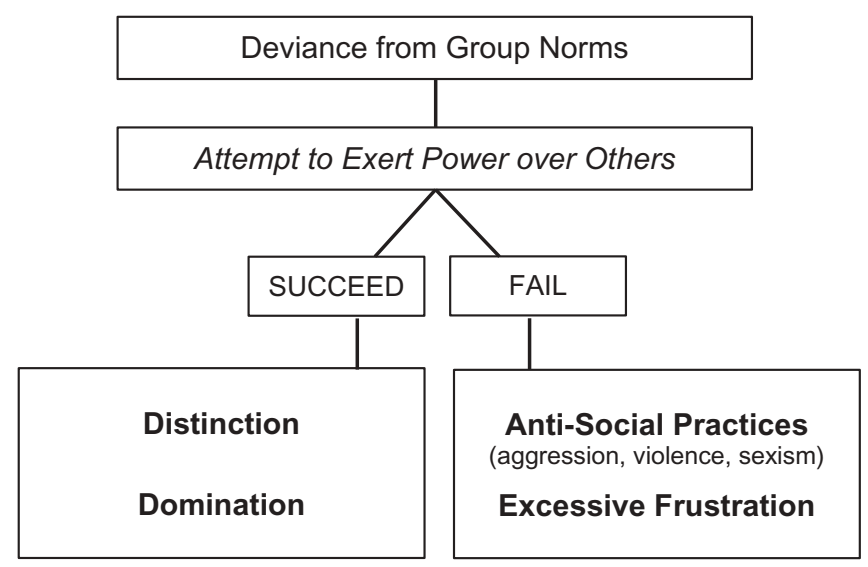

Figure 2. Typology of elites' performance of superiority in the production of symbolic boundaries. 
uniforms. Situations in which elites can be the dominant actor are multiple. They carry out claims of prestige whenever possible. At the karate dojo, I observed this behavior between practitioners of different levels. Martial arts practice involves the acceptance of a hierarchical ladder of respect. The more experienced black belts are the most respected. The colored belts, which range from brown to white, ${ }^{9}$ follow in order. This system allows beginners to display deference while learning the more advanced karate techniques from those higher up. While in principle all members agree on this practice, I observed that elites are less willing to take lessons from advanced practitioners of lower socio-economic status, who have lived in Park Slope since it was a "bad neighborhood." Many of these practitioners are construction workers, drivers, or nannies. Due to the evolutionary process of gentrification, it was more likely to find advanced black belts that were of lower socioeconomic status because they were long-term Park Slope residents and members of the dojo. On the contrary, the beginners mostly belonged to the "upper-class newcomers" social cohort. Even Sensei, the Japanese dojo Master, noticed that as the neighborhood population was changing in southern Park Slope, his karate students were changing too.

Our dojo people... more intelligent people in the dojo, some $\mathrm{PhD}$, or some managers, maybe 25 years, 30 years before, dojo people more criminals, drug dealers. Nowadays more educated people stay here. (Sensei, 68, karate Master)

Practicing karate in a place mostly populated by lower class advanced black belts endangered the elites' egos because they were not in the position of power. By coperforming karate across different courses offered in the dojo, I found a "class" boundary at play, both in terms of karate class and social class. Elites who were brown or first grade black belts strategically preferred to choose lower level courses in the intermediate class to avoid training with lower class black belts in the advanced one. Elites justified this behavior by stating they felt unprepared for the higher intensity of the advanced class, especially the sparring sessions. ${ }^{10}$ On the contrary, I observed that the intermediate class allowed those elites to be the "superior" practitioners. Because very few advanced practitioners attended the intermediate classes, elites were usually the "head students." As a result, they were in charge of carrying out the most important class ritual: the bow or, in Japanese, rei. In order to perform it, students are asked to line up in a grid pattern: the highest ranks to the left, the next behind them, and so on down the line. Brown and first grade black belts led the bow line in intermediate classes, and they steered the meditation (mokusoh) and the initial recitation of the five principles of karate. They also usually led the warm-up and the final stretch sessions and, more importantly, they acted as a point of reference for the less-experienced students during class. However, their lower class counterparts perceived elites' situated selfmeanings as diverging from the prototypical norms of the dojo, and they interpreted such distancing behavior as a sign of snobbery. As noted by Malloy and Frankie, ${ }^{11}$ one day after class:

Malloy: The austerities are the training. It's the breaking down of the body so the mind will open. That is what we do in class. Practice. That's the environment that we have. Nobody really gets involved. Like people who... "oh don't 
touch my face or fuck you!" Who do you think you are? All of that shit goes out the window, you know what I mean.

Frankie: People get treated the same way, all that nonsense goes out the window, about your class and who you are and that's what make the Dojo. (« After training conversation », May.16.2012)

Elite practitioners often misunderstood the "teaching intentions" of the lower-class advanced black belts, interpreting them as signs of bullying or reverse discrimination. Many times, the elite confessed to me in the changing room or during private conversations that they were distressed by the actions of advanced belts. They thought these practitioners were "rude" to them and were "taking advantage of their low level of technique" in order to "put them down" or "beat them." Damian expressed this unease at the end of the training. He pointed out how elites behave normatively in the group and how lower-class members counteract the disturbance.

Frankie was sparring today with Damian, who kicked him with a mae geri (front kick). As Damian threw a mae geri and went to step down, Frankie stepped back and accepted the kick. He allowed him to hit him, but his range was perfect because it didn't hit him $100 \%$. He hit him about like maybe $35 \%$. And then when he went to step down, Frankie went and swept him. And Damian fell down, seemingly embarrassed, like he didn't get "the lesson"! («Field note ", May.16.2012)

At the PSFC, I was confronted firsthand with the symbolic boundaries at play between the upper class volunteer members and the lower class workers. On the first day, I worked in the co-op's "receiving" area, where bad vegetables must be taken off the shelf and restocked. After a while, I went back to the receiving area to divide the produce into different bins. I was a bit irritated at that point, since my hands were dirty from rotten vegetables, and I was cold because I had been sorting them in the fridge for about an hour. At the same moment, another member noticed that there was a mess surrounding recycle bins; some of the salvageable vegetables had ended up in the compost trash instead of the soup kitchen one, or vice versa,

Argh, and now I'm here with my stuff to put into these bins... what do I have to do? And while trying to fix this situation, here it is, the voice of the Coop coordinator, an African American woman, screaming at me. Oh no... Maybe she was already talking to me, and I didn't realize that because I was bent over the garbage, and probably this infuriated her. Still bent over, with the bad tomatoes in my hands, from the bottom up, I turn my face toward her voice, and she was there, above my head, yelling madly at me: "You see this mess? Now clean it all up!” (« Field note », June.21.2011)

I could not even say anything at that point and remained bent over. I lowered my gaze once again, and then I realized that I had made a big mistake. I probably did not reply as she expected or wanted because she continued to scream the same things. I thought:

I don't believe this... I'm fixing this mess, what the hell does she want from me? She knows that I'm new, and I didn't make this mess! [I want to cry...] but suddenly I understood: I disrespected her, she wanted to be revered!

And once again, I turned my face upward to look at her, finally saying what she needed to hear: 
I was really right, since she calmed down and left me alone, in front of the garbage. That day, there was something deeper to be analyzed than simply an asymmetry in power. I never knew the term "alright" could be used as a sign of surrender and acceptance. In addition, having most likely been deemed an upper-class co-op member, I had the chance to experience firsthand how staff of Caribbean, African American, or Puerto Rican background treated White gentrifiers differently than their long-termPark Slope-resident counterparts. For example, at the end of my shift that day, I noticed that there were cotton gloves and aprons for members to use while doing "dirty work" in a small box in the receiving area. Even though New Yorkers usually follow the "every man for himself" ${ }^{12}$ work ethic, I found it odd that nobody told first-time volunteers like me or the other young White woman, who was wearing a large flowery skirt and a pair of red ballerinas, how to avoid getting dirty. As I discussed in the case of the dojo, the co-op worker was unfriendly to me, underlining the "fine line" among the competing selves we are constantly performing. Our performance is dependent on the intersection of social class, ethnicity, gender, and also membership in local institutions like a karate dojo or a food co-op.

In addition, by holding different volunteering positions at the PSFC, I was able to observe many forms of social stratification: the higher one's social class (and level of education), the more likely he or she was to volunteer as cashier or administrator, as opposed to working in the food packaging or maintenance areas. Despite the values of equality that permeate the PSFC, elites tend to reproduce their class status by applying for positions, like the group coordinator (or "squad leader"), that involve more responsibility. Paradoxically, the democratic PSFC's microcosm seems to provide "the stage" for elites to re-enact class divide and exercise power, as confirmed by Edna, a long-term coop member:

I was working in the office, and there was this woman coordinating, who is the most miserable, nasty person. I am a trained person, I am a therapist, I've been in group therapy, I've lived in a commune, I have faced all kinds of difficult people in my life... but, by the end of that two and a half hours I was ready to quit the Co-op! I was practically crying! She was just a bitch! She had a tone in her voice, I can't remember... but, I just remember the power! (Edna, 64, Psychotherapist).

In a private interview, one of the co-op's founders, Justin, did not deny the existence of "different styles" of volunteering. He thereby silently reaffirmed, that elites at the PSFC perform various facets of social distinction and how exclusionary behavior functions to reinforce and clarify groups' norms.

Some people are abusing the squad leader role, like they're on a power trip sometimes. "This is my three hours every 28 days I get to be this, I am the leader" I know, and the Coop is tolerant of many different styles of that. We don't micromanage that, I understand there are different styles. (Justin, 62, PSFC Manager)

With regard to the second situation, when the elites cannot be superior to ordinary people, aggression, violence, sexism, or excessive frustration may emerge. At the karate dojo, despite members usually getting along and enjoying after-training talks and company, elites displayed difficulty in accepting failure in sparring sessions. In the advanced class, when the social hierarchy is somehow reversed, elites suffer from the swift indignity of being treated as weak. They prefer to perform the kata (individual 
form) instead of working in pair for the kumite (sparring). If in the first they can manage a theatrical "impression of trained excellence" of the karate gestures, in the latter they have to confront the other fellows "face to face." It is the very physicality of kumite that contravenes the habit of good manners through which elites are socialized, as I discussed with some advanced fellows one time after class:

In the past, it was more physical. I could tell you that for sure. It was more physical in the sense that you know, people who are used to sparring with each other of course would... don't mind hitting each other. They know that they're testing their limits. But because of people that are not physically, you know, aggressive or physically strong, the hitting seems not allowed now but they're trying to help you be better, they're not trying to hurt you. But they will hit you just to you, to try and that's right. (« After training conversation » with Jack, February.17.2012)

Frequently, a fear of failure has been observed as disruptive to their embodied sense of moral superiority. This leads to a loss of self-confidence, acted out through loss of emotional control, loss of relaxed attitude, and anti-social behavior. I saw elites training beside me become more and more red-faced and angry because they could not block the blows or attack their opponent. I saw their faces becoming tauter as the pressure of the blows made them lose their posture and sometimes their balance. I observed them crying under the grin of their opponents, but the observation that struck me the most was the constant attempt of the elites to "win at all costs." They always tried to overcome fighting exercise rules with the purpose of beating their opponents, whom usually - being advanced fellows - could anticipate those intentions and in turn fight the "astute elites" even harder. Elites deviate from the group norms of a specific context by asserting their class attitudes, thereby threatening the prototypical integrity of the group. Under these circumstances, an intragroup dynamic between fellow lower class in-groupers emerges as they attempt to reassert their position of influence. I also experienced first-hand attempts from elite men practitioners to enact a disproportionate use of physical strength on the black belt women, in order to be "at least better than them," a strategy that was not always useful. Overexerting oneself makes the athlete lose speed and balance for smooth transitions.

Another exemplary case at the PSFC involved a Greek businessman, Timo, who actually looks like he could be Latino. Together with Allison, a famous novel writer who belongs to the neighborhood's celebrities group, we were all taking a small break from our volunteer shift when he engaged in a discussion about a perceived abusive behavior from a co-op worker in the receiving area:

So I said to the supervisor - and he was talking to three girls - "excuse me, can you show me how to use this machine?" And he turned around and he said "well you better learn." And you know I was surprised because it's the Co-op, and I didn't expect to be treated disrespectfully, and I said, well that was the point of me asking you how to use it, is that I need to learn how to use it. And then he said something to me in Spanish. And I said, I'm sorry I don't speak Spanish. And again he said "well you better learn, you're in Brooklyn!" and I was like, I know where I am and I'm Greek, I don't have to learn Spanish for you or anybody else (...) You expect that kind of behavior in the street in the Brooklyn or somewhere else but not at the Co-op! (Timo, 42, Self-employed).

According to Hogg, structural social class distinction affects intragroup relationships (and the making of boundaries) by "creating subgroups that may have competitive 
relations" (2001, p. 71). Aside from the fact that the manager was being overtly flirtatious with some of the women, and rude to Timo, the blow to his self-esteem and lack of verification motived Timo's performance. His gestures, tone, and his reddened face fumed with excessive frustration while demanding for the "usual" respect (or flattery) received at the coop. He also expressed a visible sense of repugnance for having being confused for a member of Brooklyn's Latino population.

As was pointed out in the theoretical introduction of this paper, ethnography as a "performative space for the full-throated acting out of everything that must be chocked back in public" (Conquergood, 1992, p. 91) is a key for the interpretation of those daily "zones of contact" between dominant elites and lower class citizens. During those "offstage" moments, elites perform their contradictory intentions, experience misunderstandings and confusion brought by urban diversity, and, as a result, they express their sense of superiority.

\section{Discussion and conclusions}

In the super-gentrified neighborhood of Brooklyn's Park Slope, economically elite residents became members of democratic associations, like karate dojos or food coops, to be socially accepted by and mingle with the local communities. These newer residents proudly exhibited appropriate progressive moral values. However, in the act of undressing themselves from exterior signs of class status, deeply-rooted interior markers of superiority were revealed in the performative off-stage practices played out in those settings. At the micro-level, an analysis of these embodied attitudes provided evidence of an understanding of the reflexive self. The research confirmed how ingroup performances are strongly influenced by class diversity. Elites addressed the distress faced when the self is constrained to different identities (class, group, role) by identifying themselves on the basis of their social class. On the other hand, lower-class members relied on meaning given by specific role-based identities. Through the production of symbolic boundaries, deviance and minority subgroups alike engaged in differential performances, relationships, and interconnections of roles (Stets \& Burke, 2000). Ultimately, elites elicited internalized repetition of hegemonic stylized acts of exclusive behavior, which served as a basis for inequality and conflict. Sometimes they felt good and confident about performing distinction and dominations. At other times, their roles constrained them, creating conditions under which elites engaged in antisocial practices and demonstrated excessive frustration. These actions highlighted the complexity of elites' contrasting need to simultaneously assimilate and distinguish themselves in urban communities. It is also worth noting that the karate dojo and the PSFC represented significant "counter-places" in which lower class members could construct counterhegemonic discourses and practices of resistance.

Understanding how elites draw symbolic boundaries is also central to the very political view of performance as a space for agency and resistance to power, challenging critical geographers to engage in this research method to reinforce our knowledge of how issues of distinction, segregation, and hegemony work spatially. Especially at the community level, these micro-ethnographies narrate the process of negotiation that enables living together, debunking the existence of emotional and moral distress among people of different social groups experiencing super-gentrification. Social mixing in 
urban neighborhoods has brought about the constant performance of competing selves participating in the production of boundaries, depending on "both as we label others and we participate in communities whose shared beliefs make a specific definition of reality intersubjectively true" (Lamont, 1992, p. 10). According to Marcus, the study of elites does not confirm "who the good and bad guys are" (1998, pp. 27-28) between the rulers and ruled and the leaders and the led. Rather, it reveals the complexity and ambiguity of their relations of domination and moral position in everyday practices in local communities of difference.

Performance ethnography has proven to be an effective method to study intersubjectivity, allowing the hidden, deeply-rooted signs of elite distinction and the tacit symbolic boundaries to transpire. This approach clearly highlights how relations of power shape elites' lives and are produced by them (Manzo, 2015), calling for a radical rethinking of the hermeneutical agency of the body. Foucault's well-known argument (1995) is that embodied practices open up an interiority and therefore constitute knowledge. This notion resembles Gramsci's idea of the politicallyengaged knowledge production of the intellectuals (1971), which must be linked to the feelings and passions of the people to make counter-hegemonic representations emerge. Therefore, the staging of elites' identities, behavior, and emotions raises important connections between body and capital accumulation. Such is especially relevant in reference to those embodied markers by which elites demonstrate their affluent social status rooted in the regime of the capital that created it (Longhurst, 2000).

\section{Notes}

1. Interactionists have been concerned with the ways in which subjective meaning emerges from encounters in situations that are always shifting and ambiguous (Blumer, 1969), socially constructed (Berger \& Luckmann, 1966), and where personal identity is formed (Mead, 1934).

2. By practice Bourdieu refers to social patterns of behavior and habitus, "durable, transposable dispositions" (1977, p. 72) by which individuals contribute to the reproduction of structure of domination.

3. These behaviors involve matters of etiquette, dress, deportment, gesture, intonation, dialect, vocabulary, small bodily movements and automatically expressed evaluations concerning both the substance and the details of life (Goffman, 1951, p. 300).

4. Prospect Park contains recreational areas, a zoo, a stage, ponds, a lagoon, picnic grounds, and different sport pitches.

5. Source: Author's elaboration on U.S. Census Bureau data for Park Slope and New York City, 1970-2010.

6. In 2009 I decided to spend a month on vacation in New York City, and I found a room for rent in what, at the time, I did not know would become the object of my research in 2011: The neighborhood of Brooklyn's Park Slope.

7. Developed by the founder Master Gichin Funakoshi.

8. The dan is the ranking system used in karate and other martial arts to indicate the level of one's ability.

9. Single character variations, in terms of disrespectful attitudes, are commonly managed by the Master, who in case of misbehavior can decide to withdraw the dojo membership. 
10. As I will explain in the section devoted to the anti-social behavior, this attitude is not very "martial," as usually it is considered an honor and a great opportunity to train with experienced practitioners.

11. All informant names have been fictionalized in order to protect anonymity.

12. As a way to say that typically co-workers do not help each other out.

\section{Acknowledgments}

This research would not have been possible without the generosity of the Food Coop members and the Karate Dojo fellows who took part in this ethnography in the neighborhood of Brooklyn's Park Slope. I also am particularly grateful to Susan Moore for her support and direction as editor, and the three anonymous reviewers whose input has significantly improved this article. Further thanks to David Bassens, Enzo Colombo, Mary Gilmartin, and Bas van Heur for their comments on various iterations of this work.

\section{Disclosure statement}

No potential conflict of interest was reported by the author.

\section{Funding}

Research and writing for this article was supported by the Irish Research Council post-doctoral fellowship scheme at Maynooth University, Ireland (grant GOIPD/2015/518) and by a Milan City Council doctoral grant-in-aid awarded at The University of Trento, Italy.

\section{ORCID}

Lidia Katia Consiglia Manzo (D) http://orcid.org/0000-0001-8530-6719

\section{References}

Aalbers, Manuel B. (2008). The financialization of home and the mortgage market crisis. Competition and Change, 12(2), 148-166.

Aalbers, Manuel B. (2016). The financialization of housing. A political economy approach. London: Routledge.

Abrams, Dominic. (1996). Social identity, self as structure, and self as process. In William Peter Robinson (Ed.), Social groups and identities: Developing the legacy of Henri Tajfel (pp. 143168). Oxford: Butterworth-Heinemann.

Abrams, Dominic, \& Hogg, Michael A. (2001). Collective identity: Group membership and selfconception. In Michael A. Hogg \& Scott Tindale (Eds.), Blackwell handbook of social psychology: Group processes (pp. 425-460). Malden, MA: Blackwell.

Andreotti, Alberta, Le Galès, Patrick, \& Moreno-Fuentes, Francisco Javier. (2015). Globalised minds, roots in the City: Urban upper-middle classes in Europe. Hoboken, NJ: Wiley-Blackwell.

Atkinson, Anthony B., \& Piketty, Thomas. (2010). Top incomes: A global perspective. Oxford: Oxford University Press.

Auslander, Philip. (2008). Theory for performance studies. New York: Routledge.

Beaverstock, Jonathan V., Hubbard, Phil, \& Short, John Rennie. (2004). Getting away with it? Exposing the geographies of the super-rich. Geoforum, 35(4), 401-407.

Bennett, Tony, Savage, Mike, Silva, Elisabeth, Warde, Alan, Gayo-Cal, Modesto, \& Wright, David. (2009). Culture, class, distinction. New York: Routledge. 
Berger, Peter L., \& Luckmann, Thomas. (1966). The social construction of reality. London: Penguin.

Blumer, Herbert. (1969). Symbolic interactionism: Perspective and method. Englewood Cliffs, NJ: Prentice-Hall.

Borsdorf, Axel, \& Hidalgo, Rodrigo. (2008). New dimensions of social exclusion in Latin America: From gated communities to gated cities, the case of Santiago de Chile. Land Use Policy, 25(2), 153-160.

Bourdieu, Pierre. (1977). Outline of a theory of practice. New York: Cambridge University Press.

Bourdieu, Pierre. (1984). Distinction: A social critique of the judgement of taste. Cambridge, MA: Harvard University Press.

Bridge, Gary, Butler, Tim, \& Lees, Loretta. (2012). Mixed communities: Gentrification by stealth? London: PolityPress.

Butler, Judith. (1988). Performative acts and gender constitution: An essay in phenomenology and feminist theory. Theatre Journal, 40(4), 519-531.

Butler, Tim, \& Lees, Loretta. (2006). Super-gentrification in Barnsbury, London: Globalization and gentrifying global elites at the neighbourhood level. Transactions of the Institute of British Geographers, 31(4), 467-487.

Clifford, James. (1988). The predicament of culture. Cambridge, MA: Harvard University Press.

Clifford, Nicholas, Cope, Meghan, Gillespie, Thomas, \& French, Shaun (Eds.). (2016). Key methods in geography. London: Sage.

Conquergood, Dwight. (1989). Poetics, play, process, and power: The performative turn in anthropology. Text and Performance Quarterly, 9(1), 82-88.

Conquergood, Dwight. (1991). Rethinking ethnography: Towards a critical cultural politics. Communication Monographs, 58(2), 179-194.

Conquergood, Dwight. (1992). Ethnography, rhetoric, and performance. Quarterly Journal of Speech, 78(1), 80-97.

Cousin, Bruno, \& Chauvin, Sébastien. (2013). Islanders, immigrants and millionaires: The dynamics of upper-class segregation in St Barts, French West Indies. In Iain Hay (Ed.), Geographies of the super-rich. Cheltenham: Edward Elgar.

Cousin, Bruno, \& Chauvin, Sébastien. (2014). Globalizing forms of elite sociability: Varieties of cosmopolitanism in Paris social clubs. Ethnic and Racial Studies, 37(12), 2209-2225.

Daloz, Jean-Pascal. (2010). The sociology of elite distinction: From theoretical to comparative perspectives. Basingstoke: Palgrave Macmillan.

Denzin, Norman K. (2014). Cultural struggles: Performance, ethnography, praxis by Dwight Conquergood, auth., and E. Patrick Johnson, ed. American Anthropologist, 116(3), 676-677.

Durkheim, Émile. (1965). The elementary forms of religious life [1912]. (Joseph Ward Swain, Trans.). New York: The Free Press.

Fernandez, Rodrigo, Hofman, Annelore, \& Aalbers, Manuel B. (2016). London and New York as a safe deposit box for the transnational wealth elite. Environment and Planning A, 48(12), 2443-2461.

Fields, Desiree. (2015). Contesting the financialization of urban space: Community organizations and the struggle to preserve affordable rental housing in New York City. Journal of Urban Affairs, 37(2), 144-165.

Foucault, Michel. (1995). Discipline and punish: The birth of the prison (2nd ed.). New York: Vintage Books.

Goffman, Erving. (1951). Symbols of class status. The British Journal of Sociology, 2(4), 294-304.

Goffman, Erving. (1956). The presentation of self in everyday life. Edinburgh: University of Edinburgh.

Goffman, Erving. (1983). The interaction order. American Sociological Review, 48(1), 1-17.

Goffman, Erving. (1989). on Fieldwork. Journal of Contemporary Ethnography, 18(2), 123-132.

Gramsci, Antonio (1971). Prison notebooks selections. (Q. Hoare \& G. Smith, Eds.). New York: International.

Gregson, Nicky, \& Rose, Gillian. (2000). Taking Butler elsewhere: Performativities, spatialities and subjectivities. Environment and Planning D: Society and Space, 18(4), 433-452. 
Hay, Iain. (2013). Geographies of the super-rich. Cheltenham : Edward Elgar.

Hogg, Michael A. (2001). Social categorization, depersonalization, and group behavior. In Michael A. Hogg \& Scott Tindale (Eds.), Blackwell handbook of social psychology: Group processes (pp. 56-85). Malden, MA: Blackwell.

Hoggart, Keith, Lees, Loretta, \& Davies, Anna. (2002). Researching human geography. London: Arnold.

Hutter, Mark. (2012). Experiencing cities. Boston, MA: Pearson.

Jackson, Kenneth T. (2004). The neighborhoods of Brooklyn (Vol. 1998). New Haven: Yale University Press.

Jackson, Michael. (1989). Paths toward a clearing: Radical empiricism and ethnographic inquiry. Journal of Chemical Information and Modeling. Bloomington: Indiana University Press.

Katz, Cindy. (1992). All the world is staged: Intellectuals and the projects of ethnography. Environment \& Planning D: Society \& Space, 10(5), 495-510.

Keister, Lisa A., \& Lee, Hang Young. (2014). The one percent: Top incomes and wealth in sociological research. Social Currents, 1(1), 13-24.

Krippner, Greta R. (2005). The financialization of the American economy. Socio-Economic Review, 3(2), 173-208.

Lamont, Michèle. (1992). Money, morals, and manners: The culture of the French and American upper-middle class. Chicago: University of Chicago Press.

Lamont, Michèle, \& Fournier, Marcel (Eds.). (1992). Cultivating differences: Symbolic boundaries and the making of inequality. Chicago: University of Chicago Press.

Lamont, Michèle, \& Molnár, Virág. (2002). The study of boundaries in the social sciences. Annual Review of Sociology, 28(1), 167-195.

Lees, Loretta. (2000). A reappraisal of gentrification: Towards a "geography of gentrification". Progress in Human Geography, 24(3), 389-408.

Lees, Loretta. (2003). Super-gentrification: The case of Brooklyn Heights, New York City. Urban Studies, 40(12), 2487-2509.

Lees, Loretta. (2008). Gentrification and social mixing: Towards an inclusive urban renaissance? Urban Studies, 45(12), 2449-2470.

Lees, Loretta. (2013). The urban injustices of new labour's "new urban renewal": The case of the aylesbury estate in London. Antipode, 46(4), 921-947.

Lees, Loretta, \& Ferreri, Mara. (2016). Resisting gentrification on its final frontiers: Learning from the Heygate Estate in London (1974-2013). Cities, 57, 14-24.

Lees, Loretta, Shin, Hyun Bang, \& Lopez-Morales, Ernesto (Eds.). (2015). Global gentrifications: Uneven development and displacement. Bristol: Policy Press.

Lees, Loretta, Shin, Hyun Bang, \& Lopez-Morales, Ernesto. (2016). Planetary gentrification. Cambridge: Polity Press.

Longhurst, Robyn. (2000). Bodies: Exploring fluid boundaries. London: Routledge.

Madison, D. Soyini. (2005). Critical ethnography: Method, ethics, and performance. Thousand Oaks, CA: SAGE.

Manzo, Lidia Katia Consiglia. (2012). On people in changing neighborhoods. Gentrification and social mix: Boundaries and resistance. A comparative ethnography of two historic neighborhoods in Milan (Italy) and Brooklyn (New York, USA). Cidades, Comunidades E Territórios, June(24), 1-29.

Manzo, Lidia Katia Consiglia (2014). "Give me a break! I'm from Brooklyn, we're not fancy». Institutions, Housing and Lifestyles in Super-gentrification process. A Field and Historical research in Park Slope, New York City. (Unpublished PhD thesis). The University of Trento, Faculty of Sociology.

Manzo, Lidia Katia Consiglia. (2015). And their struggle becomes visible. For a radical revaluation of Foucault's conception of resistance to power. In Lidia Katia Consiglia Manzo (Ed.), Culture and visual forms of power. Experiencing contemporary spaces of resistance (pp. 1-10). Champaign, IL: Common Ground Publishing.

Marcus, George E. (1998). Ethnography through thick and thin. Katalog BPS (Vol. XXXIII). Princeton: Princeton University Press. 
Mead, George Herbert. (1934). Mind, self \& society from the standpoint of a social behaviorist. Chicago: University of Chicago Press.

Myers, Norman, \& Kent, Jennifer. (2004). The new consumers: The influence of affluence on the environment. Washington, DC: Island Press.

Osman, Suleiman. (2011). The invention of brownstone Brooklyn. New York: Oxford University Press.

Peyser, Andrea. (2011, August 25). Goy-cott in park slope. The New York Post, New York.

Pow, Choon Piew. (2011). Living it up: Super-rich enclave and transnational elite urbanism in Singapore. Geoforum, 42(3), 382-393.

Richards, Alison. (2001). Shaking the frame: Erving Goffman and performance studies. Australasian Drama Studies, 39, 58-75.

Rose, Damaris, Germain, Annick, Bacqué, Marie-Hélène, Bridge, Gary, Fijalkow, Yankel, \& Slater, Tom. (2013). "Social Mix" and neighbourhood revitalization in a transatlantic perspective: Comparing local policy discourses and expectations in Paris (France), Bristol (UK) and Montréal (Canada). International Journal of Urban and Regional Research, 37(2), 430-450.

Sassen, Saskia. (2014). Expulsions: Brutality and complexity in the global economy. Cambridge, MA: The Belknap Press of Harvard University Press.

Simmel, Georg (1950). The sociology of Georg Simmel [1903]. (Translated, edited, and with and introduction by Kurt H. Wolff). New York: The Free Press.

Slater, Tom (2003). Comparing gentrification in South Parkdale, Toronto and Lower Park Slope, New York City: A "North American" model of neighbourhood reinvestment? CNR Paper 11. Retrieved from http://www.urbancentre.utoronto.ca/pdfs/curp/CNR_Parkdale-NYCGentrifica.pdf

Slater, Tom. (2006). The eviction of critical perspectives from gentrification research. International Journal of Urban and Regional Research, 30(4), 737-757.

Slater, Tom. (2009). Missing Marcuse: On gentrification and displacement. City, 13(2), 292-311.

Smith, Neil. (1996). The new urban frontier: Gentrification and the Revanchist City. London: Routledge.

Smith, Neil, \& DeFilippis, James. (1999). The reassertion of economics: 1990s gentrification in the lower east side. International Journal of Urban and Regional Research, 23(4), 638-653.

Stets, Jan E., \& Burke, Peter J. (2000). Identity theory and social identity theory. Social Psychology Quarterly, 63(3), 224-237.

Story, Louise, \& Saul, Stephanie. (2015, February 7). Stream of Foreign wealth flows to Elite New York real estate. The New York Times.

Thrift, Nigel. (2008). Non-representational theory: Space, politics, affect. The dictionary of human geography. New York: Routledge.

Turner, Victor. (1975). Revelation and divination in Ndembu ritual. Man (Vol. 12). Ithaca: Cornell University Press.

Turner, Victor. (1986). TheAnthropology of performance. New York: PAJ Publications.

Turner, Victor, \& Bruner, Edward M. (Eds.). (1986). The anthropology of experience. Urbana: University of Illinois Press.

Umezawa, Rui. (1998). The empty hand: A karate word book. New York: Weatherhill.

van Maanen, John. (1988). Tales of the field: On writing ethnography. Chicago: University of Chicago Press.

Veblen, Thorsten. (1899). The theory of the leisure class. New York: Viking Press.

Zukin, Sharon. (1982). Loft living. Culture and capital in urban change. Baltimore: The Johns Hopkins University Press.

Zukin, Sharon. (2010). Naked city. The death and life of authentic urban places. New York: Oxford University Press.

Zukin, Sharon, Kasinitz, Philip, \& Chen, Xiangming (Eds.). (2015). Global cities, local streets: Everyday diversity from New York to Shanghai. New York: Routledge. 